\title{
Differential Effect of Socio-Demographic Factors on Emotional Intelligence of Secondary School Students in Ernakulam District
}

\author{
Dixon P. Thomas ${ }^{1}$, Dr. N. K. Arjunan ${ }^{2}$
}

Keywords: Socio-Demographic, Emotional Intelligence, Secondary School, Students, Ernakulam District

Emotional intelligence has been defined as the ability to adaptively recognize, understand, manage, harness emotions both in self and others (Mayer \& Salovey 1995; Schutte et al., 1998) and to use emotion to facilitate cognitive processing (Mayer et al., 1999). Emotional intelligence has been conceptualized in the literature both as a relatively enduring trait and as ability (Mayer et al., 2002; Petrides \& Furnham, 2006; Schutte et al., 1998). Mayer et al. (2002) \& Afolabi (2004) argue that emotional intelligence is not a single trait or ability rather; it is a composite of distinct emotion reasoning abilities. Perceiving emotions consist of recognizing and interpreting the meaning of various emotional states, as well as their relations to other sensory experiences. Understanding emotions involve understanding of how basic emotions are blended to form complex emotions. Regulating emotions encompasses the control of emotions in oneself and in others. An individual's emotional intelligence is an indicator of how an individual perceives, understands and regulates emotions.

The construct of emotional intelligence incorporates in itself a number of abilities, including the ability to be aware of one's own and of other people's emotions, to be able to manage those emotions, and to understand the complex relationships that can occur between emotions and likely emotional transitions (Caner \& Salovey, 1997). On the whole, the ability called 'emotional intelligence' is not fixed for life and can be improved with suitable training (Goleman, 1995; Caner \& Salovey, 1997; Salovey \& Caner, 1990). This can mean that the ability called emotional intelligence is not an innate but acquired ability on the part of an individual who earned it through rigorous experiences and practices with a number of interpersonal situations. If this is the situation, the socio-cultural and demographic milieu in which the person lives will have a decisive role in his emotional intelligence. This study is a part of the research activity taken up

\footnotetext{
${ }^{1}$ Research Scholar, Faculty of Education, Karpagam University, Coimbatore, India

${ }^{2}$ Professor, TEC, John Mathai Centre, University of Calicut, Thrissur, India

*Responding Author

(C) 2016 I D Thomas, N Arjunan; licensee IJIP. This is an Open Access Research distributed under the terms of the Creative Commons Attribution License (http://creativecommons.org/licenses/by/2.0), which permits unrestricted use, distribution, and reproduction in any Medium, provided the original work is properly cited.
} 


\section{Differential Effect of Socio-Demographic Factors on Emotional Intelligence of Secondary School Students in Ernakulam District}

by the first author under the supervision and guidance of the second author, where an attempt was made to find out the differential effect of certain socio-demographic factors on the emotional intelligence of secondary school students from Ernakulam district.

\section{Objectives of the Study}

The specific objectives of the study are:

1. To study the emotional intelligence of secondary school students (total sample and subsamples based gender, locale, family type, age, socio economic status, ordinal position etc.),

2. To compare the selected sub-samples of secondary school students with respect to their emotional intelligence.

\section{Hypothesis of the Study}

The following hypotheses were formulated for the purpose of the study:

1. Secondary school students of Ernakulam district do not have high emotional intelligence.

2. Gender is not a significant factor in differentiating the secondary school students with regard to their emotional intelligence.

3. Residential locale is not a significant factor in differentiating the secondary school students with regard to their emotional intelligence.

4. Type of family is not a significant factor in differentiating the secondary school students with regard to their emotional intelligence.

5. Birth order is not a significant factor in differentiating the secondary school students with regard to their emotional intelligence.

6. The school type is not a significant factor in differentiating the secondary school students with regard to their emotional intelligence.

7. The socio-economic status of the family is not a significant factor in differentiating the secondary school students with regard to their emotional intelligence.

\section{METHODOLOGY}

The normative survey method was adopted for the study. It made use of a sample of 368 secondary school students (13-16 age range), selected by simple random method from Ernakulam district, Kerala. The Kerala Emotional Intelligence Scale (KEIS) developed by Arjunan \& Dixon (2014) was used to collect data. Statistical analyses were carried out with the help of SPSS 16.0.

\section{RESULT \& DISCUSSION}

The data were analyzed so as to find valid answers to the objectives specified in the study. The descriptive statistical indices such as mean (M), median, standard deviation (SD), skewness, standard error of mean, and the population values of mean of the KEIS scores for the total

(C) The International Journal of Indian Psychology, ISSN 2348-5396 (e)| ISSN: 2349-3429 (p) | 76 
Differential Effect of Socio-Demographic Factors on Emotional Intelligence of Secondary School Students in Ernakulam District

sample and sub-samples based on gender and locale were calculated to get a general picture of the emotional intelligence of the secondary school students. On the basis of the norms of the Emotional intelligence Scale, the total sample was further classified into High, Average, and Low Emotional intelligence groups. The details of the analysis carried out in this regard are presented in Table 1 and 2.

Table 1: Statistical indices relating to the Emotional intelligence Scores of Secondary School Students (Total Sample and Sub-samples)

\begin{tabular}{|l|c|c|c|c|c|}
\hline \multirow{2}{*}{$\begin{array}{c}\text { Statistical } \\
\text { Indices }\end{array}$} & \multirow{2}{*}{ Total Sample } & \multicolumn{2}{c|}{ Gender Groups } & \multicolumn{2}{c|}{ Family Type } \\
\cline { 3 - 6 } & & Boys & Girls & Joint & Nuclear \\
\hline N & 368 & 176 & 192 & 176 & 192 \\
\hline Mean & 117.25 & 115.76 & 119.77 & 119.70 & 115.00 \\
\hline Median & 118.13 & 118.13 & 120.50 & 123.00 & 116.73 \\
\hline SD & 14.69 & 15.24 & 14.19 & 15.34 & 13.74 \\
\hline Skewness & -0.322 & -0.389 & -0.224 & -0.361 & -0.423 \\
\hline Kurtosis & -0.581 & -0.571 & -0.754 & -0.828 & -0.305 \\
\hline SE & 0.766 & 1.149 & 1.02 & 1.157 & 0.991 \\
\hline \multirow{2}{*}{$\mathbf{M}_{\text {pop }} \mathbf{. 0 5}$} & 115.75 & 113.51 & 117.77 & 117.43 & 113.06 \\
\hline $\mathbf{M}_{\text {pop }} . \mathbf{0 1}$ & 118.75 & 118.01 & 121.77 & 121.97 & 116.94 \\
\hline
\end{tabular}

Table 2: Classification of the Total Sample into High-, Average-, and Low Emotional Intelligence Groups

\begin{tabular}{|c|l|c|c|}
\hline \multirow{2}{*}{ Sl. No. } & \multicolumn{1}{|c|}{ Emotional Intelligence Groups } & \multicolumn{2}{|c|}{ Subjects } \\
\cline { 2 - 4 } & $\begin{array}{l}\text { High Emotional Intelligence Group } \\
\text { (132 and above) }\end{array}$ & 71 & 19.29 \\
\hline 2 & $\begin{array}{l}\text { Average Emotional Intelligence Group } \\
\text { (Between 104 and 131) }\end{array}$ & 223 & 60.60 \\
\hline 3 & $\begin{array}{l}\text { Low Emotional Intelligence Group } \\
\text { (103 and below) }\end{array}$ & 74 & 20.11 \\
\hline \multicolumn{2}{|c|}{ Total } & 368 & $\mathbf{1 0 0 . 0 0}$ \\
\hline
\end{tabular}




\section{Differential Effect of Socio-Demographic Factors on Emotional Intelligence of Secondary School Students in Ernakulam District}

The data and results presented in Table 1 clearly indicate that the sample under study is a heterogeneous one with regard to their emotional intelligence. The highest score obtained on the Emotional intelligence Scale for the total sample is 144 and the lowest is 40 out of a possible maximum of 170, producing a range of 64 for the total sample. The value of skewness $(-0.322)$ for the total sample shows that the distribution is slightly negatively skewed, indicating that the scores are marginally shifted to the high end of the distribution. The values of skewness for the different sub-samples also show similar pattern of frequency distribution. Table 2 makes it clear that only a small proportion (19.29\%) of the secondary school students under study demonstrates a high level of emotional intelligence and as such they fall in the 'high' EI group. Majority of the subjects fall either in the 'average' $(60.60 \%)$ or in the 'low' (20.11\%) groups. The magnitude of average- and low emotional intelligence groups, together which comes about $80 \%$ of the population, indicates that the secondary school students of Ernakulam District, with the exception of a small percentage do not have high emotional intelligence. The hypothesis formulated in this context viz., Hypothesis-1, 'secondary school students of Ernakulam district do not have high emotional intelligence' is hence accepted.

\section{Comparison of the Emotional Intelligence of Gender based Sub-samples}

Comparison of the KEIS scores of the boys and girls was done to find out whether there is a significant difference between the groups with respect to their emotional intelligence. The comparison was done by applying the two-tailed test of significance for difference between means. The details of the comparison done with regard to the various groups are presented in Table 3.

Table 3: Comparison of the Emotional Intelligence of Gender based Sub-samples

\begin{tabular}{|c|c|c|c|c|c|c|}
\hline \multirow{2}{*}{ Criteria } & \multirow{2}{*}{ Sub-samples } & \multicolumn{3}{|c|}{ Statistical indices } & \multirow{2}{*}{ t-value } & \multirow{2}{*}{$\begin{array}{c}\text { Level of } \\
\text { Significance }\end{array}$} \\
\hline & & $\mathbf{N}$ & $\mathbf{M}$ & SD & & \\
\hline \multirow{2}{*}{ Gender } & Boys & 176 & 115.76 & 15.237 & \multirow{2}{*}{2.61} & \multirow{2}{*}{$\begin{array}{c}\text { Significant a } \\
0.01 \text { Level }\end{array}$} \\
\hline & Girls & 192 & 119.77 & 14.194 & & \\
\hline
\end{tabular}

The data and result presented in Table 3 show that boys and girls differ significantly in their emotional intelligence $(t=2.61 ; \mathrm{p}<0.01)$. A closer observation of the data makes it clear that, the girls of Ernakulam district have better emotional intelligence than their male counterparts. The hypothesis formulated in this context viz., Hypothesis-2, 'gender is not a significant factor in differentiating the secondary school students with regard to their emotional intelligence' is hence rejected. 


\section{Differential Effect of Socio-Demographic Factors on Emotional Intelligence of Secondary School}

Students in Ernakulam District

\section{Comparison of the Emotional Intelligence of Sub-samples based on Residential Locale}

Ernakulam district of Kerala is highly heterogeneous with regard to the geographical surroundings and socio-cultural characteristics of the residential settlements. There exist metro city, urban towns, rural villages, and tribal colonies in Ernakulam district. Hence, a simple ruralurban division seems to have no much significance in understanding the differences in behavioural characteristics of people. The present study covered students from all these geographic areas and a comparison of their emotional intelligence was done by applying oneway ANOVA, the result of which is given in Table 4.

Table 4: One-way ANOVA: Residential Locale and Emotional Intelligence

\begin{tabular}{|c|c|c|c|c|c|}
\hline & & ANO & & & \\
\hline EI & Sum of Squares & df & Mean Square & $\mathrm{F}$ & Sig. \\
\hline Between Groups & 3936.634 & 3 & 1312.211 & \multirow{3}{*}{6.146} & \multirow{3}{*}{.000} \\
\hline Within Groups & 77721.659 & 364 & 213.521 & & \\
\hline Total & 81658.293 & 367 & & & \\
\hline
\end{tabular}

As clear from Table 4, the F-value obtained is significant at 0.01 level and above. It indicates that there exist significant differences among the groups compared with regard to their emotional intelligence. To put it differently, the emotional intelligence of secondary school students differ significantly according to their residential locale. Intergroup comparisons of the obtained differences were further carried out to find out whether the obtained significant differences exist between all the pairs of groups considered. The result of the post hoc (LSD) multiple comparisons made in the context is given in Table 5.

Table 5: Post Hoc Tests for Comparisons of the Emotional Intelligence of different Group Pairs: Groups based on Residential Locale of the Students

\begin{tabular}{|c|c|c|c|c|c|c|}
\hline \multicolumn{7}{|c|}{ Multiple Comparisons } \\
\hline \multicolumn{2}{|c|}{$\begin{array}{l}\text { Emotional Intelligence } \\
\text { LSD }\end{array}$} & \multirow{2}{*}{$\begin{array}{c}\text { Mean } \\
\text { Difference } \\
\text { (I-J) }\end{array}$} & \multirow{2}{*}{ Std. Error } & \multirow{2}{*}{ Sig. } & \multicolumn{2}{|c|}{ 95\% Confidence Interval } \\
\hline (I) Locale & (J) Locale & & & & Lower Bound & Upper Bound \\
\hline \multirow{3}{*}{ Metro } & Rural & $-8.530^{*}$ & 2.102 & .000 & -12.66 & -4.40 \\
\hline & Tribal & -2.337 & 2.543 & .359 & -7.34 & 2.66 \\
\hline & Urban & $-5.695^{*}$ & 2.083 & .007 & -9.79 & -1.60 \\
\hline \multirow{3}{*}{ Rural } & Metro & $8.530^{*}$ & 2.102 & .000 & 4.40 & 12.66 \\
\hline & Tribal & $6.192^{*}$ & 2.421 & .011 & 1.43 & 10.95 \\
\hline & Urban & 2.834 & 1.932 & 143 & -.96 & 6.63 \\
\hline \multirow{2}{*}{ Tribal } & Metro & 2.337 & 2.543 & .359 & -2.66 & 7.34 \\
\hline & Rural & $-6.192^{*}$ & 2.421 & .011 & -10.95 & -1.43 \\
\hline
\end{tabular}

(c) The International Journal of Indian Psychology, ISSN 2348-5396 (e)| ISSN: 2349-3429 (p) | 79 
Differential Effect of Socio-Demographic Factors on Emotional Intelligence of Secondary School Students in Ernakulam District

\begin{tabular}{|c|c|c|c|c|c|c|}
\hline \multicolumn{7}{|c|}{ Multiple Con } \\
\hline \multicolumn{2}{|c|}{$\begin{array}{l}\text { Emotional Intelligence } \\
\text { LSD }\end{array}$} & \multirow{2}{*}{$\begin{array}{c}\text { Mean } \\
\text { Difference } \\
\text { (I-J) }\end{array}$} & \multirow{2}{*}{ Std. Error } & & \multicolumn{2}{|c|}{ 95\% Confidence Interval } \\
\hline \multirow[t]{2}{*}{ (I) Locale } & (J) Locale & & & & Lower Bound & Upper Bound \\
\hline & Urb & & &. & & \\
\hline \multirow{3}{*}{ Urban } & Metro & $5.6 c$ & & & & \\
\hline & Rural & -2.83 & & & & 6 \\
\hline & Tribal & 3.358 & 2.404 & & & \\
\hline \multicolumn{7}{|c|}{ The mean difference is significant at the 0.05 level. } \\
\hline \multicolumn{7}{|c|}{$\begin{array}{l}\text { The results of the post hoc test for multiple comparisons between means of emotional } \\
\text { intelligence scores in different locale groups show that the observed significant difference is } \\
\text { limited to certain pairs of locale based groups compared. A closer observation of the mean } \\
\text { differences (vide Table 5) shows that the significant difference exists between three pairs } \\
\text { compared viz., metro vs rural; metro vs urban; rural vs tribal. No significant difference was found } \\
\text { to exist between the metro and tribal students as well as between the rural and urban students } \\
\text { with regard to their emotional intelligence. A scrutiny of the mean difference obtained (vide } \\
\text { Table 5) makes it clear that the students from rural area excel all other locale groups in their } \\
\text { emotional intelligence, the metro group positioned at the lower end of the hierarchy. The data } \\
\text { and result presented in Table } 5 \text { reveals that the residential locale of the secondary school students } \\
\text { partially enables one to discriminate them on the basis of their emotional intelligence. The } \\
\text { hypothesis formulated in this context, viz., 'residential locale is not a significant factor in } \\
\text { differentiating the secondary school students with regard to their emotional intelligence' is hence } \\
\text { partially accepted. }\end{array}$} \\
\hline
\end{tabular}

\section{Comparison of the Emotional Intelligence on the basis of Family Type}

The emotional intelligence of the secondary school students from Joint Family and Nuclear Family was compared to find out whether there is a significant difference between the groups. The details of the comparison done with regard to the various groups are presented in Table 6 .

Table 6: Comparison of the Emotional Intelligence of Sub-samples based on Family Type

\begin{tabular}{|c|c|c|c|c|c|c|}
\hline \multirow{2}{*}{ Criteria } & \multirow{2}{*}{ Sub-samples } & \multicolumn{3}{|c|}{ Statistical indices } & \multirow{2}{*}{ t-value } & \multirow{2}{*}{$\begin{array}{l}\text { Level of } \\
\text { Significance }\end{array}$} \\
\hline & & $\mathbf{N}$ & $\mathbf{M}$ & SD & & \\
\hline \multirow{2}{*}{$\begin{array}{l}\text { Type of } \\
\text { Family }\end{array}$} & Joint Family & 176 & 118.90 & 15.542 & \multirow{2}{*}{3.28} & \multirow{2}{*}{$\begin{array}{l}\text { Significant at } \\
0.01 \text { Level }\end{array}$} \\
\hline & $\begin{array}{l}\text { Nuclear } \\
\text { Family }\end{array}$ & 192 & 113.86 & 13.928 & & \\
\hline
\end{tabular}




\section{Differential Effect of Socio-Demographic Factors on Emotional Intelligence of Secondary School Students in Ernakulam District}

The result of the two-tailed test of significance for difference between means, presented in Table 6 , show that students from the joint family and nuclear family differ significantly in their emotional intelligence $(\mathrm{t}=3.28 ; \mathrm{p}<0.01)$. Scrutiny of the data makes it clear that, the students from joint families excel their counterparts form nuclear families in their emotional intelligence. The hypothesis formulated in this context viz., Hypothesis-4, 'type of family is not a significant factor in differentiating the secondary school students with regard to their emotional intelligence' is hence rejected.

\section{Comparison of the Emotional Intelligence on the basis of Ordinal Position}

The secondary school students in different birth orders were compared so as to find out whether the ordinal position is a significant factor in discriminating them on the basis of their emotional intelligence. The data and result of the one-way ANOVA carried out in this context is given in Table 7.

Table 7: One-way ANOVA: Birth Order and Emotional Intelligence

\begin{tabular}{|c|c|c|c|c|c|}
\hline & & ANO & & & \\
\hline EI & Sum of Squares & df & Mean Square & $\mathrm{F}$ & Sig. \\
\hline Between Groups & 3039.260 & 3 & 1013.087 & \multirow{3}{*}{4.691} & \multirow{3}{*}{.003} \\
\hline Within Groups & 78619.033 & 364 & 215.986 & & \\
\hline Total & 81658.293 & 367 & & & \\
\hline
\end{tabular}

The F-value estimated is significant $(\mathrm{F}=4.691 ; \mathrm{p}<0.01)$ showing the existence of a true difference among the groups based on the ordinal position with regard to their emotional intelligence. Intergroup comparisons of the obtained differences were further carried out to find out whether the obtained significant differences exist between all the pairs of groups considered. The result of the post hoc multiple comparisons made in the context is given in Table 8 . 
Differential Effect of Socio-Demographic Factors on Emotional Intelligence of Secondary School Students in Ernakulam District

Table 8: Post Hoc Tests for Comparisons of the Emotional Intelligence of different Group Pairs: Groups based on Ordinal Position of the Students

\begin{tabular}{|c|c|c|c|c|c|c|}
\hline \multicolumn{7}{|c|}{ Multiple Comparisons } \\
\hline \multicolumn{2}{|c|}{$\begin{array}{l}\text { Emotional Intelligence } \\
\text { LSD }\end{array}$} & \multirow{3}{*}{$\begin{array}{c}\text { Mean } \\
\text { Difference } \\
\text { (I-J) }\end{array}$} & \multirow{3}{*}{ Std. Error } & \multirow{3}{*}{ Sig. } & \multirow{2}{*}{\multicolumn{2}{|c|}{ 95\% Confidence Interval }} \\
\hline \multirow{2}{*}{$\begin{array}{l}\text { (I) Birth } \\
\text { Order }\end{array}$} & \multirow{2}{*}{$\begin{array}{l}\text { (J) Birth } \\
\text { Order }\end{array}$} & & & & & \\
\hline & & & & & Lower Bound & Upper Bound \\
\hline \multirow{3}{*}{1} & 2 & $-5.330^{*}$ & 1.843 & .004 & -8.95 & -1.71 \\
\hline & 3 & .844 & 2.215 & .703 & -3.51 & 5.20 \\
\hline & 4 & 1.198 & 2.849 & .674 & -4.40 & 6.80 \\
\hline \multirow{3}{*}{2} & 1 & $5.330^{*}$ & 1.843 & .004 & 1.71 & 8.95 \\
\hline & 3 & $6.174^{*}$ & 2.100 & .003 & 2.05 & 10.30 \\
\hline & 4 & $6.528^{*}$ & 2.761 & .019 & 1.10 & 11.96 \\
\hline \multirow{3}{*}{3} & 1 & -.844 & 2.215 & .703 & -5.20 & 3.51 \\
\hline & 2 & $-6.174^{*}$ & 2.100 & .003 & -10.30 & -2.05 \\
\hline & 4 & .353 & 3.022 & .907 & -5.59 & 6.30 \\
\hline \multirow{3}{*}{4} & 1 & -1.198 & 2.849 & .674 & -6.80 & 4.40 \\
\hline & 2 & $-6.528^{*}$ & 2.761 & .019 & -11.96 & -1.10 \\
\hline & 3 & -.353 & 3.022 & .907 & -6.30 & 5.59 \\
\hline
\end{tabular}

The results of the post hoc test for multiple comparisons between means of emotional intelligence in different birth order groups show that significant differences exist only between certain pairs. True difference was found to exist between first and second born children in which the second born was found to have better emotional intelligence. Pairwise comparison of the second born with the third and fourth born also produced significant differences, wherein the third and fourth born trail behind the second born in their emotional intelligence. Significant differences were not found to exist between the first born and third born as well as between the first born and the fourth born children. It is thus evident from the foregoing discussion that the second born children outshine others in their emotional intelligence.

\section{Comparison of the Emotional Intelligence on the basis of School Type}

In order to find out the influence of the type of school system (Mono-gender vs Co-education) on emotional intelligence of secondary school students, the groups were compared by applying the two tailed test of significant differences between the means. The data and result of the analysis done in this context is given in Table 9. 
Differential Effect of Socio-Demographic Factors on Emotional Intelligence of Secondary School Students in Ernakulam District

Table 9: Comparison of the Emotional Intelligence of Sub-samples based on Type of School

\begin{tabular}{|c|c|c|c|c|c|c|}
\hline \multirow{2}{*}{ Criteria } & \multirow{2}{*}{ Sub-samples } & \multicolumn{3}{|c|}{ Statistical indices } & \multirow{2}{*}{ t-value } & \multirow{2}{*}{$\begin{array}{c}\text { Level of } \\
\text { Significance }\end{array}$} \\
\hline & & $\mathbf{N}$ & M & SD & & \\
\hline \multirow{2}{*}{$\begin{array}{l}\text { Type of } \\
\text { School } \\
\text { System }\end{array}$} & $\begin{array}{l}\text { Mono-gender } \\
\text { Schools }\end{array}$ & 188 & 115.97 & 14.440 & \multirow{2}{*}{0.39} & \multirow{2}{*}{$\begin{array}{c}\text { Not } \\
\text { Significant }\end{array}$} \\
\hline & $\begin{array}{l}\text { Co-education } \\
\text { Schools }\end{array}$ & 180 & 116.58 & 15.433 & & \\
\hline
\end{tabular}

The $\mathrm{t}$-value obtained $(\mathrm{t}=1.84 ; \mathrm{p}>0.05)$ on comparing the students from mono-gender and coeducation schools is not significant, indicating that the groups do not differ in their emotional intelligence. To put it differently, the type of school system is not a significant factor in discriminating the secondary school students on the basis of their emotional intelligence. The hypothesis formulated in this context, viz., 'the school type is not a significant factor in differentiating the secondary school students with regard to their emotional intelligence' is hence accepted.

\section{Comparison of the Emotional Intelligence on the basis of Socio-Economic Status}

In order to find out the differential effect of socio-economic status on the emotional intelligence of secondary school students, comparison was done among high-, average-, and low SES group by applying one-way ANOVA. The data and result of the analysis is given in Table 10 .

Table 7: One-way ANOVA: Socio-Economic Status and Emotional Intelligence

\begin{tabular}{|l|c|c|c|c|c|}
\hline \multicolumn{7}{|c|}{ ANOVA } \\
\cline { 1 - 4 } EI & Sum of Squares & df & Mean Square & F & \multirow{2}{*}{ Sig. } \\
\hline Between Groups & 499.078 & 2 & 249.539 & \multirow{2}{*}{1.122} & \multirow{2}{*}{.327} \\
\cline { 1 - 4 } Within Groups & 81159.215 & 365 & 222.354 & & \\
\hline Total & 81658.293 & 367 & & \\
\hline
\end{tabular}

The F-value obtained on comparing the high-, average-, and low socio-economic status groups of the secondary school students are not significant, declaring that the groups are alike with regard to their emotional intelligence. Stating differently, the socio-economic status is not a significant factor in discriminating the secondary school students on the basis of their emotional intelligence. The hypothesis formulated in this context, viz., 'the socio-economic status of the family is not a significant factor in differentiating the secondary school students with regard to their emotional intelligence' is hence accepted. 


\section{CONCLUSIONS}

1. It was found that only a small percentage of the secondary school students have high emotional intelligence while majority have average or low emotional intelligence.

2. $\quad$ Girls excel boys in their emotional intelligence

3. Secondary school students from tribal and metropolitan areas have lower emotional intelligence than those from urban and rural areas.

4. Compared to children from joint families, those from nuclear families have significantly lower emotional intelligence.

5. The secondary school students from mono-gender schools and co-education schools are alike in their emotional intelligence.

6. Socio economic status is not a decisive factor in deciding the emotional intelligence of secondary school students.

7. Birth order of the individual was found as a significant factor in discriminating secondary school students with regard to their emotional intelligence. The second born surpass children in other ordinal positions in their emotional intelligence.

\section{Acknowledgments}

The author appreciates all those who participated in the study and helped to facilitate the research process.

\section{Conflict of Interests}

The author declared no conflict of interests.

\section{REFERENCES}

Afolabi, A. O. (2004). Influence of five-factor personality attributes, need for achievement and emotional intelligence on work team interaction processes in the Niger-Delta. An unpublished Ph.D Thesis, University of Ibadan, Nigeria.

Arjunan, N. K. \& Dixon, P. T. (2014). Kerala Emotional Intelligence Scale. Coimbatore: Karpagam University.

Caner, J. D. \& Salovey, P. (1997). What is emotional intelligence? In P. Salovey \& D.J. Sluyter (Eds.), Emotional development and emotional intelligence: Educational implications. New York: Basic Books.

Goleman, D. (1995). Emotional intelligence: Why it can matter more than IQ. New York: Bantam Books.

Mayer, et al. (2002). Emotional intelligence as a standard intelligence. Emotion, 1(3): 232-42.

Mayer, J. D., Caruso, D. R., \& Salovey, P. (1999). Emotional intelligence meets traditional standards for an intelligence. Intelligence, 27(4): 267-298.

Mayer, J., \& Salovey, P. (1995). Emotional intelligence and the construction and regulation of feelings. Applied \& Preventive Psychology, 4 (3): 197-208. 


\section{Differential Effect of Socio-Demographic Factors on Emotional Intelligence of Secondary School Students in Ernakulam District}

Petrides, K.V. \& Furnham, A. (2006). The role of trait emotional intelligence in a genderspecific model of organizational variables, Journal of Applied Social Psychology, (36) 2: 552-69.

Salovey, P. \& Caner, J. (1990). Emotional intelligence. Imagination, Cognition, and Personality, 9: $185-211$.

Schutte, N. S., Malouff, J. M., Hall, L. E., Haggerty, D. J., Cooper, J. T., Golden, C.J., \& Dornheim, L. (1998). Development and validation of a measure of emotional intelligence. Personality and individual differences, 25: 167-177.

How to cite this article: D Thomas, N Arjunan (2016), Differential Effect of SocioDemographic Factors on Emotional Intelligence of Secondary School Students in Ernakulam District, International Journal of Indian Psychology, Volume 3, Issue 4, No. 59, ISSN 2348-5396 (e), ISSN: 2349-3429 (p), DIP: 18.01.065/20160304, ISBN: 978-1-365-26307-1 